Esta publicación cientifica en formato digital es continuidad de la revista impresa ISSN-Versión Impresa 0798-1406 / ISSN-Versión on line 2542-3185Depósito legal pp
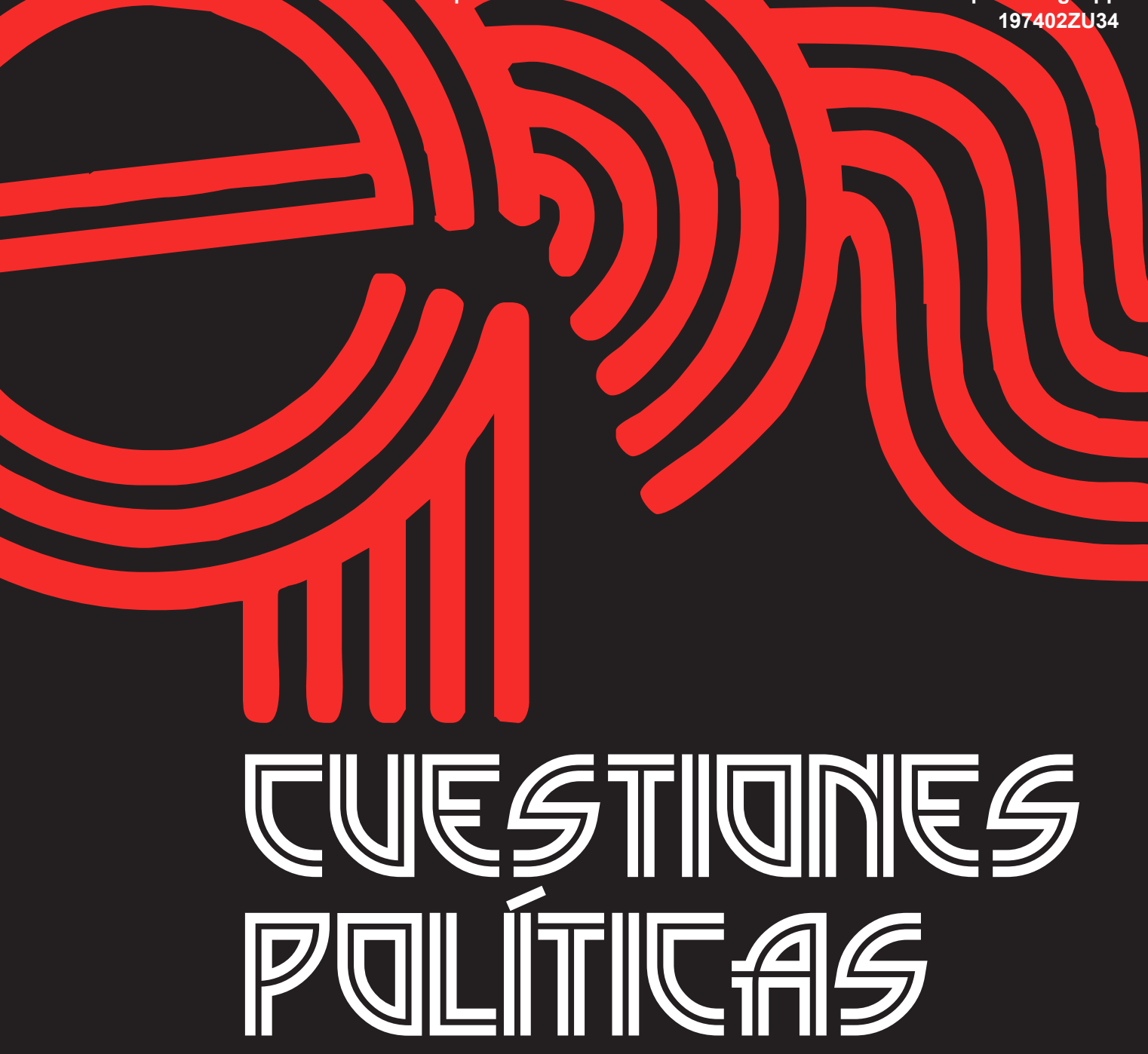

Instituto de Estudios Políticos y Derecho Público "Dr. Humberto J. La Roche" de la Facultad de Ciencias Jurídicas y Políticas de la Universidad del Zulia Maracaibo, Venezuela
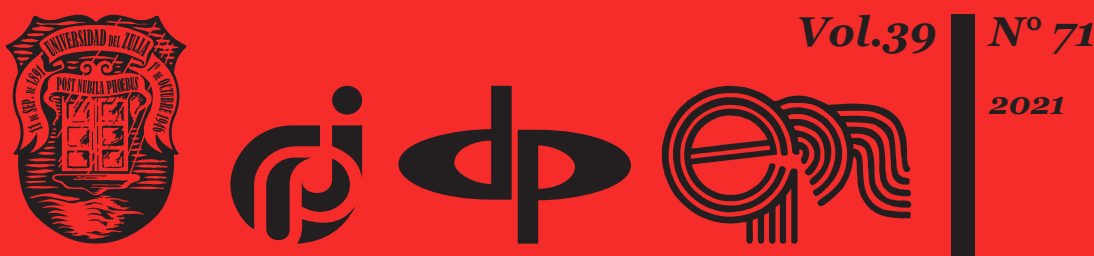


\title{
Criminal policy in countering corruption crimes related to bribery and other illegal remuneration (legislative aspect)
}

\author{
DOI: https://doi.org/10.46398/cuestpol.3971.42 \\ Pavel Nikonov *
}

\begin{abstract}
Criminal policy is part of state policy, defining the main objectives and means to influence crime through legislative activities related to change, first, criminal, criminal-procedural, criminal-executive legislation. Through a scientific methodology of a documentary nature, the objective of the research is to analyze the criminal and legal policy of the State in the fight against crimes related to bribery and other illegal remuneration. It should be noted that the criminal policy of crimes related to bribery and other illegal remuneration is currently in crisis. It is concluded that there is a tendency to increase the range of criminal acts related to illegal remuneration, to broaden the scope of the criminal regulation of liability for illegal remuneration by making changes and additions to the composition of offences related to illegal remuneration, and to criminalize new types of acts related to unlawful remuneration, which is associated with the assessment of the role of illegal remuneration as a particularly dangerous criminal phenomenon, which has a significant negative impact
\end{abstract} on protected public relations.

Keywords: criminal-legal policies; corruption; anti-corruption; bribery; tampering.

* Irkutsk Law Institute (branch) of the University of Prosecution of the Russian Federation, Irkutsk, Russia. ORCID ID: https://orcid.org/oooo-0003-2721-0481 


\section{Política criminal en la lucha contra los delitos de corrupción relacionados con el soborno y otras remuneraciones ilegales (aspecto legislativo)}

\section{Resumen}

La política criminal es parte de la política del estado, definiendo los principales objetivos y medios para influir en el crimen a través de actividades legislativas relacionadas con el cambio, en primer lugar, la legislación penal, penal-procesal, penal-ejecutiva. Mediante una metodología científica de carácter documental el objetivo de la investigación consiste en analizar la política penal y legal del Estado en la lucha contra los delitos relacionados con el soborno y otras remuneraciones ilegales. Cabe señalar que la política criminal de los delitos relacionados con el soborno y otras remuneraciones ilegales se encuentra actualmente en crisis. Se concluye que existe una tendencia a aumentar la gama de actos delictivos relacionados con la remuneración ilegal, a ampliar el alcance de la regulación penal de la responsabilidad por remuneración ilegal mediante la realización de cambios y adiciones a la composición de los delitos relacionados con la misma, y a tipificar como delito nuevos tipos de actos relacionados con la remuneración ilegal, que está asociada con la evaluación del papel de la remuneración ilegal como un fenómeno delictivo particularmente peligroso, que tiene un impacto negativo significativo en las relaciones públicas protegidas.

Palabras clave: políticas penales-jurídicas; corrupción; lucha contra la corrupción; soborno; manipulación.

\section{Introduction}

Countering crime is one of the most important areas of the state's activities, implemented within the framework of its criminal policy. Criminal policy, being a part of public policy itself, includes some components that correspond to the structure of crime: the fight against organized, corruption crimes, attacks on the person, etc. A lot of scientific research are currently devoted to criminal policy issues, however, a unified approach as to what should be included in the content of this concept has not been developed in the doctrine of criminal law. 


\section{The theoretical basis of the state's criminal-legal policy}

\subsection{Approaches to understanding the criminal - legal policy of the state}

There are now some relatively contradictory approaches to understanding the criminal policy of the state in science. According to the first approach, the concept of «criminal policy of the state» is considered in a broad sense, where the concept of «criminal-legal policy of the state» is part of the first.

According to proponents of this approach, the criminal policy of the state covers all the activities of state and local governments, as well as public associations and citizens to fight crime and eliminate its negative consequences. At the same time, in the opinion of A. A. Herzenzon, tools of both legal and other origin (environmental, medical, economic measures) can be used to achieve these goals (Herzenzon, 1970; Kazyrytski, 2020). This approach is partially reflected in the definition formulated by N.A. Belyaev (1986), who under the criminal policy understands

The direction of state and public bodies and organizations based on objective laws of development of society to protect the interests of citizens from criminal encroachments by the use of punishment or replacement of punishment measures of administrative or public influence to the persons who committed them, as well as by preventing crimes by means of the threat of punishment (1986: 15).

Proponents of the second approach assume that only legal tools and only authorized law enforcement agencies can be used to combat crime. At the same time, the priority is the use of legal means that have found enshrining in criminal, criminal procedure, and criminal-executive legislation (Zubkov and Zubkova, 2002).

Thus, the content of the criminal policy includes the policy of criminallegal, criminal-procedural, criminal-executive, crime prevention policy, criminal-tactical policy, penitentiary, criminal-preventive, criminal, operational-investigative, etc. (Troshchenko, 2011). Categories of criminallegal policy and criminal policy of the state in this case also correlate with each other as part and whole and are not considered as equivalent. This approach includes the definition of criminal policy given by A.I. Korobeyev (2019), according to which:

Criminal policy is a general line developed by the state, defining the main directions, goals and means of influencing crime by forming criminal, criminalprocedural, criminal-executive legislation, regulating the practice of its application, as well as by developing and implementing measures aimed at preventing crimes (2019: 16).

Finally, the proponents of the third approach view the criminal policy of the State in a narrow sense. Therefore, it is more than a criminal policy, but 


\footnotetext{
Pavel Nikonov

706

Criminal policy in countering corruption crimes related to bribery and other illegal remuneration (legislative aspect)
}

a criminal policy of the state, as the proponents of this approach consider only the means of combating crime, which are directly reflected in the criminal law.

The concepts of "criminal policy of the state» and "criminal-legal policy of the state» are identified with each other in this approach. N.A. Lopashenko (2004: 266), who writes that the concepts of «criminal policy» and «criminal-legal policy» are identical to each other, also concludes: "Criminal policy is no different from the policy of criminal law; criminallegal policy does not include criminal-procedural or criminal-executive policies».

\subsection{The concept and content of the state's criminal policy}

Preferring the second approach, we believe it is necessary to support the position of A.I. Korobeyev (2019: 19) in the definition of criminallegal policy as the part of criminal policy. It develops the basic objectives, principles, directions, and objectives of criminal and legal influence on crime.

One of the components of criminal-legal policy is law-making, which is based on the detection of those negative social phenomena, the fight against which is possible by criminal means, if there is an objective need of society in criminal-legal regulation. Criminal law is socially conditioned. The criminal-legal prohibition is a consequence of the reflection of the real needs of society in criminal law. Therefore, the task of the legislator is an adequate response to changes in the system and structure of public relations in order to take under legal protection the most valuable and significant of them.

Of course, the content of criminal and legal policy is reduced not only to legislative activity, it includes the activities of law enforcement. However, the effectiveness and quality of law enforcement depends on the quality of the criminal law. Therefore, we believe it is necessary to focus on the legislative aspect of the criminal-legal policy in the sphere of countering corruption crimes related to bribery and other types of illegal remuneration.

\section{Stages of implementation of criminal policy in the field of countering corruption crimes}

\subsection{Establishing anti-corruption legislation}

The criminal and legal policy in countering corruption crimes related to bribery and other types of illegal remuneration, its legal component is an improvement of legislative measures to counter this type of crime. The 
study showed that such a policy in its evolutionary development has passed several stages. At the same time, each stage has specific features that have become determinants for a new round of law-making.

The first stage of the establishment of legislation to counter corruption crimes related to bribery and other forms of illegal remuneration is the adoption and ratification of international obligations and treaties (Council of Europe's Convention on Criminal Responsibility for Corruption, 1999); United Nations Convention Against Corruption, 2003).

Numerous anti-corruption regulations had already been adopted in the Russian Federation by the time the Criminal Code of the Russian Federation came into force in 1996. However, there is a different approach of the legislator to assess corruption crimes in terms of their public danger and to impose penalties for their commission.

Thisperiodismarkedbytheliberalization ofcriminallegislationinthearea of anti-bribery, which is associated with the mitigation of penalties even for the commission of qualified bribery. Thus, in the Criminal Code of the Russian Federation in 1996, for receiving a bribe in the presence of special qualifying features was sentenced from seven to twelve years with the confiscation of property or without it, and for giving bribes in the presence of qualifying signs was established the maximum penalty of imprisonment up to eight years.

In addition, the criminal law in the original version did not contain a special rule establishing responsibility for mediation in bribery. Judicial practice assessed these socially dangerous acts from the position of complicity in bribery (assistance in the receipt of the bribe and assistance in giving of the bribe).

Since 2007, there has been a further improvement of domestic legislation in the field of countering corruption crimes by adopting a significant number of legal acts: strategies, concepts, laws, presidential decrees, orders of various ministries and departments.

\subsection{Specification of anti-corruption legislation}

Since 2011, the second stage can be identified, which was marked by the adoption of numerous laws that have made significant adjustments in the regulation of criminal responsibility for corruption crimes.

In addition, the responsibility for these forms of misconduct was seriously differentiated, namely:

1. a significant (in total over 25 thousand rubles) and a particularly large (in total more than 1 million rubles) amounts of bribes have been established. 


\section{Pavel Nikonov \\ 708 \\ Criminal policy in countering corruption crimes related to bribery and other illegal remuneration (legislative aspect)}

2. the differentiation of responsibility for bribery, depending on its size, has been improved.

3. established responsibility for the commission of the act by a group of persons under preliminary collusion and organized by a group in Article 291 of the Criminal Code of the Russian Federation.

4. the procedure for calculating the fine for bribery in the size, multiple value of the subject of the bribe is fixed. However, we would like to point out that the criminal significance and determination of the effectiveness of this type of punishment is the subject of separate study.

5. chapter 15 «Confiscation of Property» of the Criminal Code of the Russian Federation has been introduced, extending its effect to certain types of corruption crimes related to bribery and other types of illegal remuneration.

6. the rule establishing responsibility for mediation in bribery with differentiation depending on certain circumstances was criminalized (Article 291 of the Criminal Code of the Russian Federation, 1996).

The novelty of the criminal law in the framework of the fight against corruption crimes was the rule enshrining the measures of criminal punishment for the promise or offer of mediation in bribery, established by the Federal Law from May 4, 2011 No. 97-FL.

However, it is impossible to recognize this criminal-legal prohibition completely new, previously there were preconditions for its emergence, just over a hundred years ago in Russia there was such a composition of the illegal act in the form of bribery at the stages of promise and offer. The 1845 Sentencing of Criminal and Correctional Offences in Article 372-382 chapter VI «On bribery and collusive corruption» section V «On crimes and misdemeanors in the service of the state and public» recognized bribery as a completed crime at a time when «money, things and other benefits were only promised to the official as promises» provided that the official had complied with the expected actions (Semykina, 2016).

These articles recognized crimes when money, belongings and other benefits were only promised to the official as promises, but in this case it was taken into account whether the law was «in the case of the relaxation of the law» as a result of the bribe or it was not «an incentive to do so»; the amount of money, belongings and other goods donated or promised was insignificant; bribes were handed over to the official not directly, but through an intermediary under the pretext of any imaginary legal and specious transaction (under the pretext of losing, selling, exchange, etc.) (Shiryaev, 1916: 425-427, 479-481). 
In the Criminal Statute of 1903, the legislator already allocated one rule on responsibility for bribing jurors (including those on the reserve list), which indicated the «acceptance» of bribes offered to him (or them) as the end of the crime (A. 659) (Criminal Act, 1903: 65-66, 266-268).

In part 5 Article 291 of the Criminal Code of the Russian Federation (1996) the legislator made provisions for prohibition of promise or suggestion of mediation in bribery. However, as the study of these legislative innovations showed, certain provisions of the Criminal Code of the Russian Federation were formulated in violation of legal and technical rules, in conflict with the provisions of the General Part of the Criminal Code of the Russian Federation, in connection with which numerous problems of a practical nature have given rise to.

Establishing responsibility for promise or suggestion of mediation in bribery the Legislator does not connect these actions with a size the way it was done in part 1 Article 291 of the Criminal Code of the Russian Federation (1996). This way, actions written in part 5 Article 291 of the Criminal Code of the Russian Federation (1996) are considered as crimes regardless the size of the bribe.

In addition, the legislator for a not quite clear reason made a roll in the direction of a significant increase in responsibility for bribery under Article 291 of the Criminal Code of the Russian Federation, which already included five parts. At the same time, the sanction of part 5 Article 291 of the Criminal Code of the Russian Federation for bribery in a particularly large amount set a penalty of imprisonment for a period of seven to twelve years with a fine of seventy times the amount of the bribe.

\subsection{Transforming criminal law in the fight against corruption}

The third phase (2016-2017) is related to the transformation of criminal law in the field of anti-corruption, which was significantly influenced by the issuance of decrees of the President of the Russian Federation from April 2, 2013 No. 309 «On measures to implement certain provisions of the Federal Anti-Corruption Act» (Decree of the President of the Russian Federation, 2013a), April 2, 2013 No. 310 «On measures to implement certain provisions of the Federal Law on the Control of Compliance of Expenditures of persons replacing public office and other persons and their income» (Decree of the President of the Russian Federation, 2013b); from April 1, 2016 No. 147 «On the National Anti-Corruption Plan for 2016-2017» (Decree of the President of the Russian Federation, 2016).

In connection with the publication of legal acts, the legislator, embodying the goals of criminal policy at the current stage of the development of the state, strengthens the responsibility for corrupt officials. Thus, the Federal Law No. 324-FZ of July 3, 2016, the Criminal Code of the Russian Federation 
was supplemented by Article 204 and 291, providing responsibility for petty commercial bribery and petty bribery, in which the amount of bribery or bribes is no more than ten thousand rubles (Federal Law of the Russian Federation, 2016).

It is worth noting that the need to establish responsibility for petty bribery arose before the moment of criminalization in the national anticorruption plan for 2010-2011 (Decree of the President of the Russian Federation, 2010). In this document, the term «domestic corruption» was defined as «corrupt violations, which citizens encounter most often».

In an explanatory note to the draft of Federal Law was noted that in 2012-2015 most criminal cases on the facts of commercial bribery, giving or receiving bribes were initiated with the sum of less than ten thousand rubles. That was why it was suggested that the small public danger of such crimes should be considered and that the need to implement the principle of fairness in criminalizing those acts should be taken into account. At the same time, it was proposed in the sanctions of this article to establish a more lenient punishment than provided for by sanctions of Part 1 of Article 290 and Part 1 of Article 291 of the Criminal Code of the Russian Federation (Explanatory note to the draft Federal Law, 2016).

Establishing responsibility for criminal acts of corruption of up to ten thousand rubles is a logical legislative decision, corresponding to the spirit of changes previously made in Articles 204, 290, 291 of the Criminal Code of the Russian Federation, according to which a significant, large, and especially large number of bribes or bribery were provided as qualifying features.

\subsection{Development of the concept and improvement of legislation in accordance with the National Anti-Corruption Plan 2018- 2020}

The fourth phase (2017-2019) is related to the development of the concept and the improvement of legislation in accordance with the National Anti-Corruption Plan for 2018-2020 (Decree of the President of the Russian Federation, 2018).

In accordance with the anti-corruption strategy of the Prosecutor's Office, the prosecutor's supervision of the implementation of the law on public and municipal service has been strengthened.

In addition, the improvement of criminal legislation in countering such crimes continued. Thus, on May 4, 2018, the amendments made by the Federal Law of April 23, 2018 no. 99-FZ (Federal Law of the Russian Federation, 2018) in the Criminal Code of the Russian Federation and the Criminal Code of the Russian Federation, aimed at strengthening the 
responsibility for violations in the procurement of goods, works, services for the provision of state or municipal needs, in connection with which the composition of the crime was criminalized (Article 200 of the Criminal Code of the Russian Federation, 1996)). The norm is designed quite similar to the composition of commercial bribery, establishes responsibility for two counter-acts: illegal transfer of the subject of bribery and illegal receipt of it by representatives of the customer.

\subsection{Criminalization of the composition of corruption offences related to bribery and other forms of illegal remuneration}

The fifth phase (2020 to the present) is related to the ongoing criminalization of the composition of corruption crimes related to bribery and other types of illegal remuneration. Federal law of October 27, 2020, No. 352-FZ introduced responsibility for bribing the arbitrator Article 200 of the Criminal Code of the Russian Federation (Federal Law of the Russian Federation, 2020).

As can be seen from the periodization of the stages of the evolution of the criminal-legal policy to counter the corruption crimes related to bribery and other types of illegal remuneration, it occurred in leaps and bounds, but at the same time it was caused by a whole set of factors. This includes the adoption of international obligations by the Russian Federation; the emergence of new types of crimes involving bribery and other new types of crimes related to giving and receiving illegal remuneration and the need for a legislative response to them; need to deepen the differentiation of criminal responsibility for crimes related to bribery and other types of illegal remuneration, and the need for a legislative response to them (Anyushina et al., 2021; Korobeyev, 2019; Szakonyi, 2021).

The process of law-making during all the five stages of the development of criminal and legal policy in the sphere of countering corruption crimes related to bribery and other types of illegal remuneration, makes it possible to conclude that it is haphazard and inconsistent, which is due to the initial lack of a clear concept to counteract this type of act. In turn, the haphazard nature of the change in criminal law in the designated sphere led to the discrepancy of individual norms among themselves, difficulties in law enforcement.

\section{Conclusion}

Speaking about the current state of the criminal-legal policy of the state as a whole, most scientists note that it is in crisis. This applies fully to the criminal-legal policy in the area of countering corruption crimes related to bribery and other types of illegal remuneration. We believe 
that the development of a scientifically sound concept for fighting crime and reforming criminal legislation in the area of countering corruption crimes related to bribery and other illegal remuneration can contribute to the development of a scientifically sound concept for fighting crime and reforming criminal law. Implementation of such a concept would help to bring criminal law with a criminological reality, implement systemic measures to prevent corruption crimes related to bribery and other forms of illegal remuneration.

The current legislation has significantly increased the responsibility for illegal remuneration, depending on the area of public relations in which the encroachment is committed, the range of persons involved in criminal activities, the nature of their actions (inactions). Monitoring of existing legislation shows a tendency to increase the range of criminal acts related to illegal remuneration. This appears to be due to an assessment of the role of illegal remuneration as a particularly dangerous criminal phenomenon, which has a significant negative impact on legally protected public relations.

In recent years, there has been a steady trend of expanding the scope of criminal regulation of liability for illegal remuneration by making changes and additions to the composition of crimes related to such and criminalizing new types of acts related to illegal remuneration. Thus, since only 2018 and till present times The Criminal Law has been completed with new elements of crime: Article 2005 of the Criminal Code of The Russian Federation "Bribing of a contact service worker, contract manager, the member of buying commission" and Article 200 of the Criminal Code of the Russian Federation «Bribing an arbitrator (awarder)».

\section{Bibliographic References}

ANYUSHINA, Marina; BESTAEVA, Elena; SUYAZOV, Viacheslav; SHIRYAEVA, Svetlana; SHUTIKOVA, Nataliya. 2021. "National Security: Theoretical-Legal Research” In: Cuestiones Políticas. Vol. 39, No. 69, pp. 317-325.

BELYAEV, Nikolay A. 1986. Criminal-legal policy and ways to implement it. Leningrad University Publishing House. Leningrad, USSR.

COUNCIL OF EUROPES CONVENTION ON CRIMINAL RESPONSIBILITY FOR CORRUPTION. 1999, January 27.

CRIMINALACT, HIGHLY SIGNED MARCH 22, 1903. 1903. Tipografiya SanktPeterburgskogo aktsionernogo obshchestva «Slovo». St. Petersburg, Russian. 
CRIMINALCODEOFTHERUSSIAN FEDERATION No.63-FZ.1996. Available online. In: http://www.kremlin.ru/acts/bank/9555. Consultation date: 15/04/2021.

DECREE OF THE PRESIDENT OF THE RUSSIAN FEDERATION No. 147. 2016. Available online. In: http://www.kremlin.ru/acts/bank/40657. Consultation date: 15/04/2021.

DECREE OF THE PRESIDENT OF THE RUSSIAN FEDERATION No. 309. 2013a. Available online. In: http://www.kremlin.ru/acts/bank/36988. Consultation date: 15/04/2021.

DECREE OF THE PRESIDENT OF THE RUSSIAN FEDERATION No. 310. 2013b. Available online. In: http://www.kremlin.ru/acts/bank/36989 . Consultation date: 15/04/2021.

DECREE OF THE PRESIDENT OF THE RUSSIAN FEDERATION No. 378. 2018. Available online. In: http://www.kremlin.ru/acts/bank/37123. Consultation date: 15/04/2021.

DECREE OF THE PRESIDENT OF THE RUSSIAN FEDERATION No. 460. 2010. Available online. In: http://www.kremlin.ru/acts/bank/38589. Consultation date: 15/04/2021.

EXPLANATORY NOTE TO THE DRAFT FEDERAL LAW ON AMENDING THE CRIMINAL CODE OF THE RUSSIAN FYDERATION AND THE RUSSIAN CODE OF CRIMINAL PROCEDURE. 2016. May 23. Available online. In: http://www.kremlin.ru/acts/news/51981. Consultation date: 15/04/2021.

FEDERAL LAW OF THE RUSSIAN FEDERATION No. 324-FZ. 2016. July 3. "On amendments to the Criminal Code of the Russian Federation and the Criminal Procedure Code of the Russian Federation". Available online. In: http://www.kremlin.ru/acts/bank/41078. Consultation date: 15/04/2021.

FEDERAL LAW OF THE RUSSIAN FEDERATION No. 352-FZ. 2020. October 27. "On amendments to the Criminal Code of the Russian Federation and Article 151 of the Criminal Procedure Code of the Russian Federation". Available online. In: http://www.kremlin.ru/acts/bank/45973. Consultation date: 15/04/2021.

FEDERAL LAW OF THE RUSSIAN FEDERATION No. 99-FZ. 2018. Available online. In: https://rg.ru/2018/04/25/fz99-dok.html. Consultation date: 15/04/2021. 
HERZENZON, Alexey A. 1970. Criminal law and sociology (the problems of criminal law and criminal policy). Law Literature. Moscow, USSR.

KAZYRYTSKI, Leonid. 2020. "Fighting corruption in Russia: its characteristics and purpose" In: Social and Legal Studies. Vol. 29, No. 5, pp. 421-443.

KOROBEYEV, Alexandr I. 2019. Criminal and legal policy of Russia: from genesis to crisis. Yurlitinform. Moscow, Russia.

LOPASHENKO, Natalya A. 2004. Basics of criminal-legal impact. Yurid. tsentr Press. Saint Petersburg, Russia.

SEMYKINA, Olga I. 2016. "The historical origins of bribery" In: Russian Law Journal. Vol. 4, pp. 93-100.

SHIRYAEV, Valerian N. 1916. Bribery and corruption in the context of general study about official crimes: criminal law research. Tip. Gub. Pravleniya. Yaroslavl, Russian.

SZAKONYI, David. 2021. "Private sector policy making: business background and politicians' behavior in office" In: Journal of Politics. Vol. 83, No. 1, pp. $260-276$.

TROSHCHENKO, Roman A. 2011. "Criminal law policy as part of the criminal policy of the state" In: Voennoe pravo (Military Law). Vol. 1, pp. 156-164.

UNITED NATIONS CONVENTION AGAINST CORRUPTION. 2003. October 31. New York, USA.

ZUBKOV, Alexandr I; ZUBKOVA, Valentina I. 2002. "The problems of reforming criminal (punitive) policy at the present stage" In: Russian Law Journal. Vol. 5, pp. 23-32. 

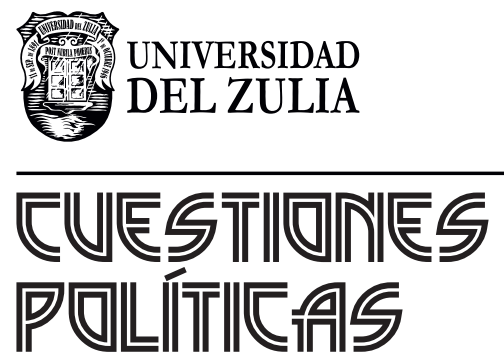

Vol. 39 N $^{\circ} 71$

Esta revista fue editada en formato digital y publicada en diciembre de 2021, por el Fondo Editorial Serbiluz, Universidad del Zulia. Maracaibo-Venezuela 